\title{
Unexpected Ligand Lability in Condition of Water Oxidation Catalysis
}

Lifen Yan, Ruifa Zong, ${ }^{\S}$ and Yulia Pushkar*

Department of Physics, Purdue University, 525 Northwestern Ave, West Lafayette, Indiana, 47907, United States

${ }^{\S}$ Department of Chemistry, University of Houston, 112 Fleming Building, Houston, Texas, 77204, United States

*To whom correspondence should be addressed: ypushkar@purdue.edu, +1 (765) 496-3279 


\begin{abstract}
In the search for rational design of improved water oxidation catalysts, enhanced catalytic activities were reported for single site $\mathrm{Ru}$ catalysis with $\mathrm{Ru}$-iodide coordination. As these complexes are not initially capable of proton coupled electron transfer (PCET) and $\mathrm{Ru}=\mathrm{O}$ formation, a proposal was put forward on the generation of catalytically active 7-coordinate $\mathrm{Ru}$ species. We tested this hypothesis by EPR and X-ray spectroscopy and found that $\left[\mathrm{Ru}^{\mathrm{II}}(\mathrm{bpy})(\mathrm{tpy}) \mathrm{I}\right]^{+}$only serves as a precursor for formation of $\left[\mathrm{Ru}^{\mathrm{IV}}(\mathrm{bpy})(\mathrm{tpy})=\mathrm{O}\right]^{2+}$. Upon oxidation with excess of $\mathrm{Ce}^{\mathrm{IV}}$ the $\mathrm{Ru}-\mathrm{I}$ bond quickly dissociates with formation of $\left[\mathrm{Ru}^{\mathrm{III}}(\mathrm{bpy})(\mathrm{tpy}) \mathrm{H}_{2} \mathrm{O}\right]^{3+}$ and $\left[\mathrm{Ru}^{\mathrm{IV}}(\mathrm{bpy})(\mathrm{tpy})=\mathrm{O}\right]^{2+}$ complexes. The catalytic steady state was composed of $95 \%\left[\mathrm{Ru}^{\mathrm{IV}}(\mathrm{bpy})(\mathrm{tpy})=\mathrm{O}\right]^{2+}$ species. Thus, introducing the $\mathrm{Ru}-\mathrm{I}$ bond into initial catalysts does not serve to improve catalyst design. This manuscript also shows how EXAFS can directly probe transition metal-halogen interaction for in situ catalysis.
\end{abstract}




\section{Introduction}

$\mathrm{Ru}$ based complexes are widely used in homogeneous catalysis [1, 2]. Some of them exist in a form which contains a Ru-halogen bond in the catalyst precursor or in the active form of the catalyst. When such complexes are dissolved in coordinating solvents or added to reaction mixtures, it is sometimes difficult to establish the dynamics of halogen exchange. For diamagnetic complexes, NMR can be used to monitor the resonance of organic ligands and draw conclusions about the halogen ligands' exchange with solvent [3] but this technique is not applicable for paramagnetic $\mathrm{Ru}^{\mathrm{III}}, \mathrm{Ru}^{\mathrm{IV}}$ and $\mathrm{Ru}^{\mathrm{V}}$ complexes and their intermediates. Here we show that X-ray absorption spectroscopy (XAS) can serve as a very sensitive and direct probe of the metal-halogen binding as well as report on the overall electronic structure of the Ru center. This study focuses on analyzing the water oxidation mechanism in single site Ru based catalysts for artificial photosynthesis. The realization of artificial photosynthesis carries the promise of abundant and clean solar fuels. However, the process requires an efficient and durable water oxidation catalyst. Mononuclear Ru-based water oxidation catalysts are currently under active investigation in an effort to uncover the fundamental principles controlling their catalytic activity [3-13]. A mononuclear Ru-based catalyst usually contains polypyridine ligands and one water molecule coordinated to $\mathrm{Ru}$. The role of ligands in catalytic water oxidation by mononuclear ruthenium complexes is summarized in a recent review by Zeng and coworkers [14]. Molecular Ru containing complexes remain the prime choice for mechanistic studies as series of complexes are available with varying redox potentials, ligand environment and catalytic activities. Thus, a detailed analysis of these complexes will help to understand overall principals controlling the catalytic water oxidation and result in design of more active molecules with higher stability. 
In single site $\mathrm{Ru}$ catalysts, a water molecule bound to $\mathrm{Ru}^{\mathrm{II}}$ is capable of proton coupled electron transfer (PCET) when both electron and proton are removed from the catalyst during oxidation to prevent charging of the complex. This process produces the oxidized $\mathrm{Ru}^{\mathrm{IV}}=\mathrm{O}$ and $\mathrm{Ru}^{\mathrm{V}}=\mathrm{O}$ species [8, 15-18]. However, some water oxidation catalysts have been reported which are seemingly incapable of PCET as they lack a ligand suitable for deprotonation, such as water [3, 19]. For instance, $\left[\mathrm{Ru}(\mathrm{bpy})\left(\right.\right.$ tpy)I]I catalyst lacks an $\mathrm{H}_{2} \mathrm{O}$ bound to $\mathrm{Ru}$ but evolves more oxygen than the parent $\left[\mathrm{Ru}(\mathrm{bpy})(\mathrm{tpy}) \mathrm{H}_{2} \mathrm{O}\right]^{2+}$ complex [3]. This calls for an investigation of potential reasons for improved catalysis. The importance of steric strain on reactivity has been noticed for complexes with no water ligand on $\mathrm{Ru}[19]$. To explain these unexpected observations the expansion of $\mathrm{Ru}$ coordination sphere to 7 has been proposed to accommodate water as a 7th ligand and allow for PCET and catalytic activity leading to O-O bond formation [3, 5]. Formation of 7-coordinated species was also implicated in water oxidation catalysis by $\mathrm{Ru}^{\mathrm{II}}(\mathrm{X})_{2} \mathrm{~L}$ type complexes (where $\mathrm{H}_{2} \mathrm{~L}$ is 2,2'-bipyridine-6,6'dicarboxylic acid and $\mathrm{X}$ can be monodentate ligand such as 4picoline) $[20,21]$.

In this study we investigate claims of 7-coordinated Ru intermediate in [Ru(bpy)(tpy)I]I and the potential role of this new pathway for design of better catalysts of water oxidation. Our spectroscopic EXAFS (Extended X-ray Absorption Fine Structure) analysis has shown that in the catalytic cycle, a 7-coordinate $\mathrm{Ru}$ intermediate is not a major species. Instead, the $\left[\mathrm{Ru}^{\mathrm{IV}}(\mathrm{bpy})(\mathrm{tpy})=\mathrm{O}\right]^{2+}$ species was observed as catalytic steady state intermediate. Thus, inclusion of halogen atoms in the Ru coordination sphere instead of $\mathrm{H}_{2} \mathrm{O}$ molecules will unlikely result in a new class of catalysts with significantly improved reactivity. Our results also illustrate significantly different behavior for $\mathrm{Ru}-\mathrm{I}$ and $\mathrm{Ru}-\mathrm{Cl}$ bonds under appropriate conditions for water oxidation. $\mathrm{Ru}-\mathrm{Cl}$ interaction is retained under strongly oxidizing conditions over the investigated 
period of time and the complex is not catalytically active. This observation reinforces the finding that $\left[\mathrm{Ru}^{\mathrm{IV}}(\mathrm{bpy})(\mathrm{tpy})=\mathrm{O}\right]^{2+}$ is a prerequisite of catalytic activity.

\section{Experimental}

Sample Preparation. Throughout this study the $\left[\mathrm{Ru}^{\mathrm{II}}(\mathrm{bpy})(\mathrm{tpy}) \mathrm{I}\right]^{+}\left(\mathrm{bpy}=2,2^{\prime}\right.$-bipyridine, tpy $=$ 2,2'; 6',2"-terpyridine) complex was used as a $\mathrm{I}^{-}$salt. Note that all experiments with $\left[\mathrm{Ru}^{\mathrm{II}}(\mathrm{bpy})(\mathrm{tpy}) \mathrm{I}\right] \mathrm{I}$ salt dissolved in water should be performed immediately (within 2 minutes) to avoid any exchange of Ru-I with water. For optimal experimentation the $[\mathrm{Ru}$ (I) $($ bpy)(tpy)I]I solution was aliquoted into small plastic tubes and frozen for further use. $\left[\mathrm{Ru}^{\mathrm{II}}\right.$ (bpy)(tpy) $\left.\mathrm{H}_{2} \mathrm{O}\right] \mathrm{Cl}_{2}$ is obtained by incubation of $\left[\mathrm{Ru}^{\mathrm{II}}(\mathrm{bpy})(\mathrm{tpy}) \mathrm{Cl}\right] \mathrm{Cl}$ in water for $24 \mathrm{~h}$. Ultrapure (Type 1) water (resistivity $18.2 \mathrm{M} \Omega \mathrm{cm}$ at $25{ }^{\circ} \mathrm{C}$, TOC $4 \mu \mathrm{g} / \mathrm{L}$ ) was used for solutions. All samples were prepared in 0.1 $\mathrm{M} \mathrm{HNO}_{3} \mathrm{pH} 1.0$ (Catalog No. 225711 from Sigma Aldrich). Oxidant solutions were prepared fresh daily by dissolving $\mathrm{Ce}\left(\mathrm{NH}_{4}\right)_{2}\left(\mathrm{NO}_{3}\right)_{6} \cdot 4 \mathrm{H}_{2} \mathrm{O}$ in $0.1 \mathrm{M} \mathrm{HNO}_{3}$. A Cary 300 Bio UV-Vis spectrophotometer (Varian Inc.) was used to monitor UV-Visible spectra $\left(5 \times 10^{-5} \mathrm{M}\right.$ concentration). Solutions for preparation of electron paramagnetic resonance (EPR) samples were bubbled with argon to displaced dissolved oxygen.

EPR Measurements. Low-temperature X-band EPR spectra were recorded by using a Bruker EMX X-band spectrometer equipped with an X-Band CW microwave bridge. The sample temperature was maintained at $20 \mathrm{~K}$, unless otherwise indicated, by use of an Air Products LTR liquid helium cryostat. Spectrometer conditions were as follows: microwave frequency, 9.65 GHz; field modulation amplitude, $10 \mathrm{G}$ at $100 \mathrm{kHz}$; microwave power, $31.70 \mathrm{~mW}$. Standard EPR sample tubes were filled with sample through all of the resonator space, a septum was placed on top and sample space was evacuated to prevent oxygen condensation. Whenever relative signal intensities are discussed, measurements were conducted on the same day and under the same 
conditions to allow direct comparison of the signal intensities. Field calibration was checked versus a DPPH (2,2-diphenyl-1-picrylhydrazyl) standard.

Oxygen $\left(\mathrm{O}_{2}\right)$ Evolution Measurements. Oxygen evolution was measured with a PC-operated Clark type polarographic oxygen electrode from Oxygraph System (Hansatech Instruments Ltd.). The sample was housed within a hermetic borosilicate glass reaction vessel, thus preventing penetration of any atmospheric oxygen. Calibration was carried out by measurements of the signal from $\mathrm{O}_{2}$-saturated water in an open reaction vessel. Sodium dithionite, an oxygen depleting agent, was added to the water, and the drop in the signal was related to the solubility of oxygen in water at room temperature $(276.26 \mu \mathrm{mol} / \mathrm{L})$. The glass vessel was thoroughly washed with water and then $0.8 \mathrm{~mL}$ of $0.55 \mathrm{mM}$ Ru solution in water was added. A defined number of $\mathrm{Ce}^{\mathrm{IV}}$ equivalents (usually 20 equiv in $1 \mathrm{M} \mathrm{HNO}_{3}$ ) were carefully added by means of a Hamilton syringe into the chamber through a plunger screw, and oxygen evolution was measured as a function of time. The dilution of $\mathrm{Ce}^{\mathrm{IV}}$ solution was adjusted to $10: 1$ to allow for final $\mathrm{pH}=1$.

Ru K-edge X-ray Absorption Spectroscopy (XAS) Measurements. Ru K-edge XAS spectra were collected at the Advanced Photon Source (APS) at Argonne National Laboratory on the BM-20 beamline at incident photon energy $23 \mathrm{keV}$ and average current of $100 \mathrm{~mA}$. The radiation was monochromatized by a $\mathrm{Si}(110)$ crystal monochromator. The intensity of the X-rays was monitored by three ion chambers $\left(\mathrm{I}_{0}, \mathrm{I}_{1}\right.$ and $\left.\mathrm{I}_{2}\right)$ filled with $70 \%$ nitrogen and $30 \%$ argon and placed before the sample $\left(\mathrm{I}_{0}\right)$ and after the sample $\left(\mathrm{I}_{1}\right.$ and $\left.\mathrm{I}_{2}\right)$. Ru metal was placed between the $\mathrm{I}_{1}$ and $I_{2}$ and its absorption was recorded with each scan for energy calibration. Plastic (Lexan) EXAFS sample holders (inner dimensions of $12 \mathrm{~mm} \times 3 \mathrm{~mm} \times 3 \mathrm{~mm}$ ) filled with frozen solutions were inserted into pre-cooled $(20 \mathrm{~K})$ cryostat. The samples were kept at $20 \mathrm{~K}$ in a He atmosphere at ambient pressure. Data were recorded as fluorescence excitation spectra using a 
Ge 13-element energy-resolving detector. Solid samples were diluted with BN powder in a 1:5 ratio, pressed between mylar tape, and measured in the cryostat in transmission mode. In order to reduce the risk of sample damage by X-ray radiation, $80 \%$ flux was used in the defocused mode (beam size $1 \times 8 \mathrm{~mm}$ ) and no damage was observed in multiple scans. The samples were also protected from the X-ray beam during motor movements by a shutter synchronized with the scan program. Additionally, low flux measurements (only $10 \%$ of beamline flux) were done on reactive intermediates to demonstrate the same EXAFS results. No more than 5 scans were taken at each sample position at any condition.

$\mathrm{Ru}$ XAS energy was calibrated by the first maxima in the derivative of the ruthenium metal XANES (X-ray Absorption Near Edge Structure) spectrum (22117 eV). EXAFS scan with 10 eV steps in the pre-edge region (21967-22102 eV), 1-eV steps $(22102-22117 \mathrm{eV})$ through the edge and $0.05 \AA^{-1}$ steps from $\mathrm{k}=2.0-16 \AA^{-1}$ were used. As reference compounds for high Ru oxidation states, $\quad \mathrm{Ru}^{\mathrm{IV}}$ and $\mathrm{Ru}^{\mathrm{V}}, \quad \mathrm{Ru}^{\mathrm{IV}}$ oxide and tetra-n-propylammonium bis-2-hydroxy-2ethylbutyrato(oxo) ruthenate(V)[22] were used.

Extended X-Ray Absorption Fine Structure (EXAFS) Data Analysis. The Athena software was used for data processing[23]. The energy scale for each scan was normalized using a ruthenium metal standard, and scans for same samples were added. Data in energy space were pre-edge corrected, normalized, deglitched (if necessary), and background-corrected. The processed data were next converted to the photoelectron wave vector $(k)$ space and weighted by $k^{3}$. The electron wave number is defined as $k=\left[2 m\left(E-E_{0}\right) / \hbar^{2}\right]^{1 / 2}$, where $E_{0}$ is the energy origin or the threshold energy. The $k$-space data were truncated near the zero crossings $\left(k=3.90\right.$ to $\left.15.20 \AA^{-1}\right)$ before Fourier transformation. The $k$-space data were transferred into the Artemis Software for curve fitting. To fit the data, the Fourier peaks were isolated separately, the peaks were grouped 
together, or the entire (unfiltered) spectrum was used. The individual Fourier peaks were isolated by applying a Hanning window to the first and last $15 \%$ of the chosen range, leaving the middle $70 \%$ untouched. Curve fitting was performed using ab initio-calculated phases and amplitudes from the FEFF8 program from the University of Washington [24]. Ab initio-calculated phases and amplitudes were used in the EXAFS equation [25]

$$
\chi(k)=S_{0}^{2} \sum_{j} \frac{N_{j}}{k R_{j}^{2}} f_{\text {eff }}\left(\pi, k, R_{j}\right) e^{-2 \sigma_{j}^{2} k^{2}} e^{-2 R_{j} / \lambda_{j}(k)} \sin \left(2 k R_{j}+\phi_{i j}(k)\right)
$$

where $N_{j}$ is the number of atoms in the $j$ th shell, $R_{j}$ is the mean distance between the absorbing atom and the atoms in the $j$ th shell, $f_{\text {eff }}\left(\pi, k, R_{j}\right)$ is the ab initio amplitude function for shell $j$, and the Debye-Waller term $e^{-2 \sigma_{j}^{2} k^{2}}$ accounts for damping caused by static and thermal disorder in absorber-backscatterer distances. The mean free path term $e^{-2 R_{j} / \lambda_{j}(k)}$ reflects losses caused by inelastic scattering, where $\lambda_{j}(k)$ is the electron mean free path. The oscillations in the EXAFS spectrum are reflected in the sinusoidal term $\sin \left(2 k R_{j}+\phi_{i j}(k)\right)$, where $\phi_{i j}(k)$ is the ab initio phase function for shell $j$. This sinusoidal term shows the direct relation between the frequency of the EXAFS oscillations in $k$-space and the absorber-backscatterer distance. $S_{0}^{2}$ is an amplitude reduction factor.

The EXAFS equation (Eq. S1) was used to fit the experimental Fourier isolated data ( $q$-space) as well as unfiltered data ( $k$-space) and Fourier transformed data ( $R$-space) using $N, S_{0}^{2}, E_{0}, R$, and $\sigma^{2}$ as variable parameters (see fit results in Table 1). $N$ refers to the number of coordination atoms surrounding $\mathrm{Ru}$ for each shell. The quality of fit was evaluated by $R$-factor and the reduced $\chi^{2}$ value. The deviation in $E_{0}$ should be less than or equal to $10 \mathrm{eV}$. $R$-factor less than $2 \%$ denotes that the fit is good enough, whereas $R$-factor between $2 \%$ and $5 \%$ denotes that the fit is correct 
within a consistently broad model. ${ }^{5}$ The reduced $\chi^{2}$ value is used to compare fits as more absorber-backscatter shells are included to fit the data. A smaller reduced $\chi^{2}$ value implies a better fit. Similar results were obtained from fits done in $k-, q^{-}$, and $R$-spaces.

Cl K-edge XANES measurements. Cl K-edge XANES spectra were collected at the Advanced Photon Source (APS) at Argonne National Laboratory on beamline 9-BM at a photon energy of 2.3-3.0 keV and an average current of $100 \mathrm{~mA}$. A Si(111) crystal monochromator with approximately $0.3 \mathrm{eV}$ energy resolution was used, and the intensity of the incident X-rays were monitored by an ion chamber $\left(\mathrm{I}_{0}\right)$ in front of the sample. The solution samples were prepared by dissolving the $[\mathrm{Ru}(\mathrm{bpy})(\mathrm{tpy}) \mathrm{Cl}] \mathrm{Cl}$ at $1 \mathrm{mM}$ concentration in $0.1 \mathrm{mM} \mathrm{HNO} 3(\mathrm{pH}=1)$ or in water. Data on solutions were recorded as fluorescence excitation spectra using a 4-element energyresolving detector. The solution samples were kept at $80 \mathrm{~K}$ using a Linkam cryostage in a He atmosphere at ambient pressure. To reduce X-ray induced sample damage, $80 \%$ flux was used; no damage was observed in consecutive scans. No more than three scans were taken at each sample position. A Ru metal standard was measured every day for energy calibration, with the edge position being determined by the inflection point evaluated as second derivative zerocrossing. 


\section{Results and Discussion}

Here we report EPR and X-ray spectroscopy analysis of $[\mathrm{Ru}(\mathrm{bpy})(\mathrm{tpy}) \mathrm{I}] \mathrm{I}$ complex to characterize reactive intermediates under water oxidation conditions using cerium ammonium nitrate $\left(\mathrm{Ce}^{\mathrm{IV}}\right)$ as chemical oxidant in $0.1 \mathrm{M} \mathrm{HNO}_{3}$. All solutions of $[\mathrm{Ru}(\mathrm{bpy})(\mathrm{tpy}) \mathrm{I}] \mathrm{I}$ were used immediately to avoid exchange of Ru-I with water. The spectroscopic behavior of $[\operatorname{Ru}(\text { bpy })(\text { tpy }) \mathrm{I}]^{+}$is found to be critically different from the one reported for the similar $[\mathrm{Ru}(\mathrm{bpy})(\mathrm{tpy}) \mathrm{Cl}]^{+}$complex [8]. Figure 1 shows EPR spectra obtained after oxidation of $[\mathrm{Ru}(\mathrm{bpy})(\mathrm{tpy}) \mathrm{I}] \mathrm{I}$ with 1 to 7 equivalents of $\mathrm{Ce}^{\mathrm{IV}}$. While oxidation of $\left[\mathrm{Ru}^{\mathrm{II}}(\mathrm{bpy})(\mathrm{tpy}) \mathrm{Cl}\right]^{+}$and $\left[\mathrm{Ru}^{\mathrm{II}}(\mathrm{bpy})(\mathrm{tpy}) \mathrm{H}_{2} \mathrm{O}\right]^{2+}$ with one equiv of $\mathrm{Ce}^{\mathrm{IV}}$ results in full conversion to corresponding $\mathrm{Ru}^{\text {III }}$ complexes with distinct EPR signals [8], addition of 1 equiv of $\mathrm{Ce}^{\mathrm{IV}}$ to [Ru(bpy)(tpy)I]I results in an EPR silent sample. The addition of 2 to 7 equiv to solutions of [Ru(bpy)(tpy)I]I results in an EPR signal with a g-tensor identical to $\left[\mathrm{Ru}^{\mathrm{III}}(\mathrm{bpy})(\mathrm{tpy}) \mathrm{H}_{2} \mathrm{O}\right]^{3+}$, with a maximal intensity detected with 5 equiv of $\mathrm{Ce}^{\mathrm{IV}}$ (Figure 1 and Table S1). We have not observed any spectral EPR components which can be assigned to the $\left[\mathrm{Ru}^{\mathrm{III}}(\mathrm{bpy})(\mathrm{tpy}) \mathrm{I}\right]^{2+}$ complex or iodide-containing radicals in samples frozen within $30 \mathrm{sec}$ after addition of $\mathrm{Ce}^{\mathrm{IV}}$ (data not shown) as well as in samples incubated with $\mathrm{Ce}^{\mathrm{IV}}$ for 2 minutes (Figure 1). Thus, the $\left[\mathrm{Ru}^{\mathrm{III}}(\mathrm{bpy})(\mathrm{tpy}) \mathrm{I}^{2+}\right.$ complex is likely unstable. The larger number of oxidative equivalents required to produce $\left[\mathrm{Ru}^{\text {III }} \text { (bpy)(tpy) } \mathrm{H}_{2} \mathrm{O}\right]^{3+}$ is likely due to oxidation of iodide ions. Further oxidation of $\left[\mathrm{Ru}^{\mathrm{III}} \text { (bpy)(tpy) } \mathrm{H}_{2} \mathrm{O}\right]^{3+}$ to $\left[\mathrm{Ru}^{\mathrm{IV}}(\text { bpy)(tpy) }=\mathrm{O}]^{2+}\right.$ explains the decrease in $\left[\mathrm{Ru}^{\mathrm{III}}(\text { bpy })(\text { tpy }) \mathrm{H}_{2} \mathrm{O}\right]^{3+}$ EPR signal after increasing $\mathrm{Ce}^{\mathrm{IV}}$ concentration. In the $\left[\mathrm{Ru}^{\mathrm{II}}(\mathrm{bpy})(\mathrm{tpy}) \mathrm{H}_{2} \mathrm{O}\right]^{2+}$ complex at $\mathrm{pH}=1$, the oxidation potential of $\mathrm{Ru}^{\mathrm{II}} / \mathrm{Ru}^{\mathrm{III}} \sim 1.05 \mathrm{~V}$ and $\mathrm{Ru}^{\mathrm{III}} / \mathrm{Ru}^{\mathrm{IV}} \sim 1.24 \mathrm{~V}$ are relatively close. According to the Pourbaix diagram [26], conversion of $\mathrm{I}_{2}$ to $\mathrm{IO}_{3}{ }^{-}$happens around $1.15-1.2 \mathrm{~V}$, which is very similar to the potential for $\mathrm{Ru}^{\mathrm{III}} / \mathrm{Ru}^{\mathrm{IV}}$ conversion. This explains why with 7 equiv of $\mathrm{Ce}^{\mathrm{IV}}$ 
$\left[\mathrm{Ru}^{\mathrm{III}}\left(\text { bpy) }(\text { tpy }) \mathrm{H}_{2} \mathrm{O}\right]^{3+}\right.$ remains present in the mixture as oxidative $\mathrm{Ce}^{\mathrm{IV}}$ equivalents are used for oxidation of $\mathrm{I}^{-}$ligand and counter ion. The addition of 20 equiv of $\mathrm{Ce}^{\mathrm{IV}}$ results in an EPR silent sample with a residual EPR signal that is very similar to the one recorded for $\left[\mathrm{Ru}^{\mathrm{II}}(\mathrm{bpy})\left(\text { tpy) } \mathrm{H}_{2} \mathrm{O}\right]^{2+}\right.$ oxidized with 20 equiv, (Figure S1, S2 and S3).

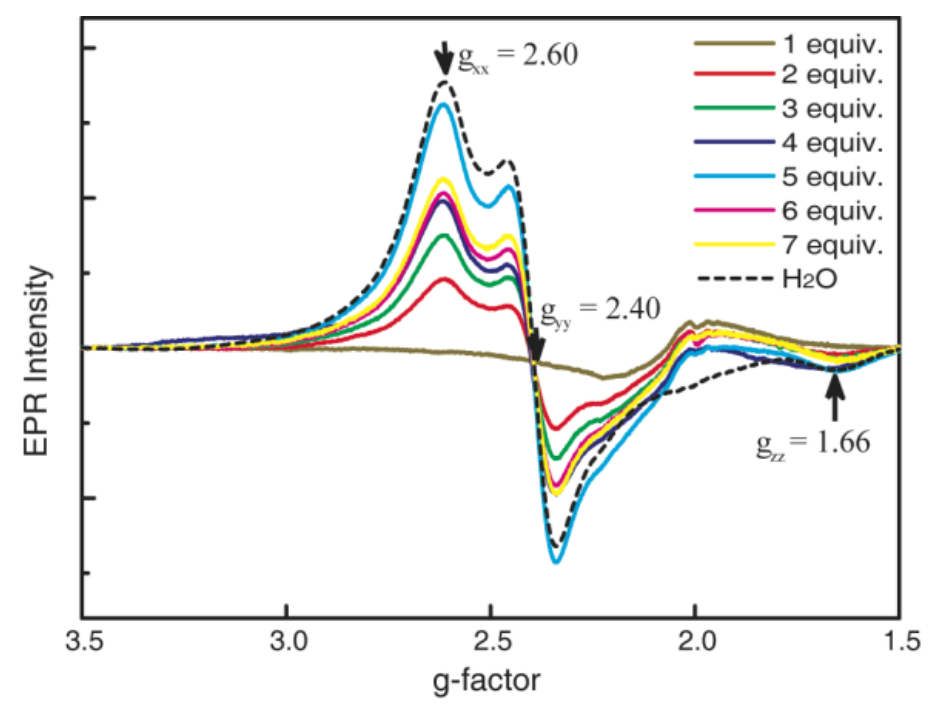

Figure 1. X-Band EPR (20 K) of [Ru $\left.{ }^{\mathrm{II}}(\mathrm{bpy})(\mathrm{tpy}) \mathrm{I}\right]^{+}$complex oxidized with 1-7 equiv of $\mathrm{Ce}^{\mathrm{IV}}$ and frozen after mixing 2 min, compared with $\left[\mathrm{Ru}^{\mathrm{III}} \text { (bpy)(tpy) } \mathrm{H}_{2} \mathrm{O}\right]^{3+}$ (black dashed) obtained by oxidation of $\left[\mathrm{Ru}^{\mathrm{II}}(\mathrm{bpy})\left(\text { tpy) } \mathrm{H}_{2} \mathrm{O}\right]^{2+}\right.$ with 1 equiv of $\mathrm{Ce}^{\mathrm{IV}}$. Catalyst concentration is $1 \mathrm{mM}$ in 0.1 $\mathrm{M} \mathrm{HNO}_{3}$.

To verify changes in the Ru oxidation state and Ru-I bonding under oxidation we used $\mathrm{Ru} \mathrm{K}$ edge X-ray absorption spectroscopy (XAS), a technique which is uniquely sensitive to the oxidation state and coordination environment of Ru centers [8, 16, 27]. Figure $2 \mathrm{~A}$ shows Ru Kedge XANES spectra for $[\mathrm{Ru}(\mathrm{bpy})(\mathrm{tpy}) \mathrm{I}] \mathrm{I}$ for samples frozen within 30 seconds following the addition of $\mathrm{Ce}^{\mathrm{IV}}$. Measurements were done at $20 \mathrm{~K}$ and with a defocused $\mathrm{X}$-ray beam to avoid radiation damage. The spectra show a small shift indicating only partial oxidation of the $\mathrm{Ru}^{\mathrm{II}}$ 
center upon adding 1 and 2 equiv of $\mathrm{Ce}^{\mathrm{IV}}$ (Figure 2A). Paired with the results of EPR, this suggests that oxidation of another component in the system (e.g., iodide) takes place. In $\left[\mathrm{Ru}(\text { bpy)(tpy)Cl}]^{+}\right.$and $\left[\mathrm{Ru}(\mathrm{bpy})(\mathrm{tpy}) \mathrm{H}_{2} \mathrm{O}\right]^{2+}$, the addition of 1 equiv of $\mathrm{Ce}^{\mathrm{IV}}$ results in the formation of an $\mathrm{Ru}^{\mathrm{III}}$ complex as verified by XANES and EPR [8].
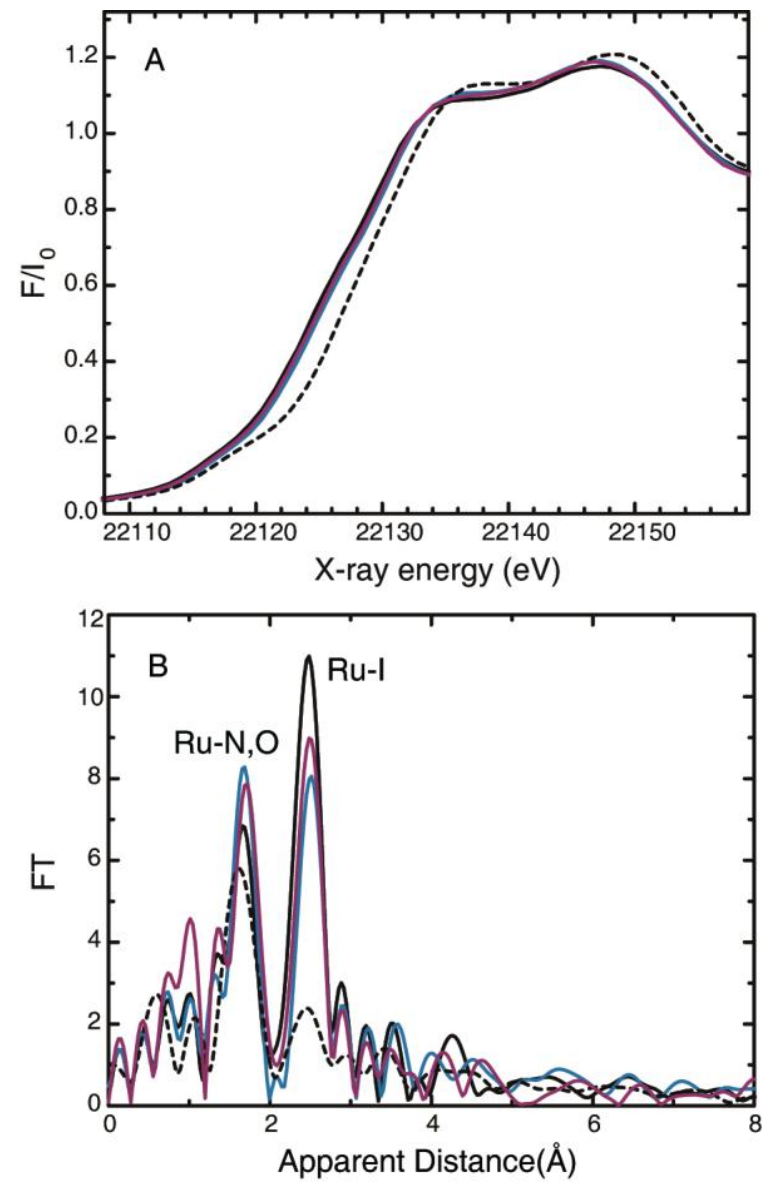

Figure 2. Normalized Ru K-edge XANES (A) and Fourier transforms of $k^{3}$-weighted Ru EXAFS (B) of the starting $\left[\mathrm{Ru}^{\mathrm{II}}(\mathrm{bpy})(\mathrm{tpy}) \mathrm{I}\right]^{+}$(black), $\left[\mathrm{Ru}{ }^{\mathrm{II}}(\mathrm{bpy})(\mathrm{tpy}) \mathrm{I}\right]^{+}$complex oxidized with 1 equiv (purple), 2 equiv (light blue), and 20 equiv (black dashed line) of $\mathrm{Ce}^{\mathrm{IV}}$. There is $1 \mathrm{mM}$ catalyst concentration in $0.1 \mathrm{M} \mathrm{HNO}_{3}$. Samples were frozen $30 \mathrm{sec}$ after mixing and measured at $20 \mathrm{~K}$. 

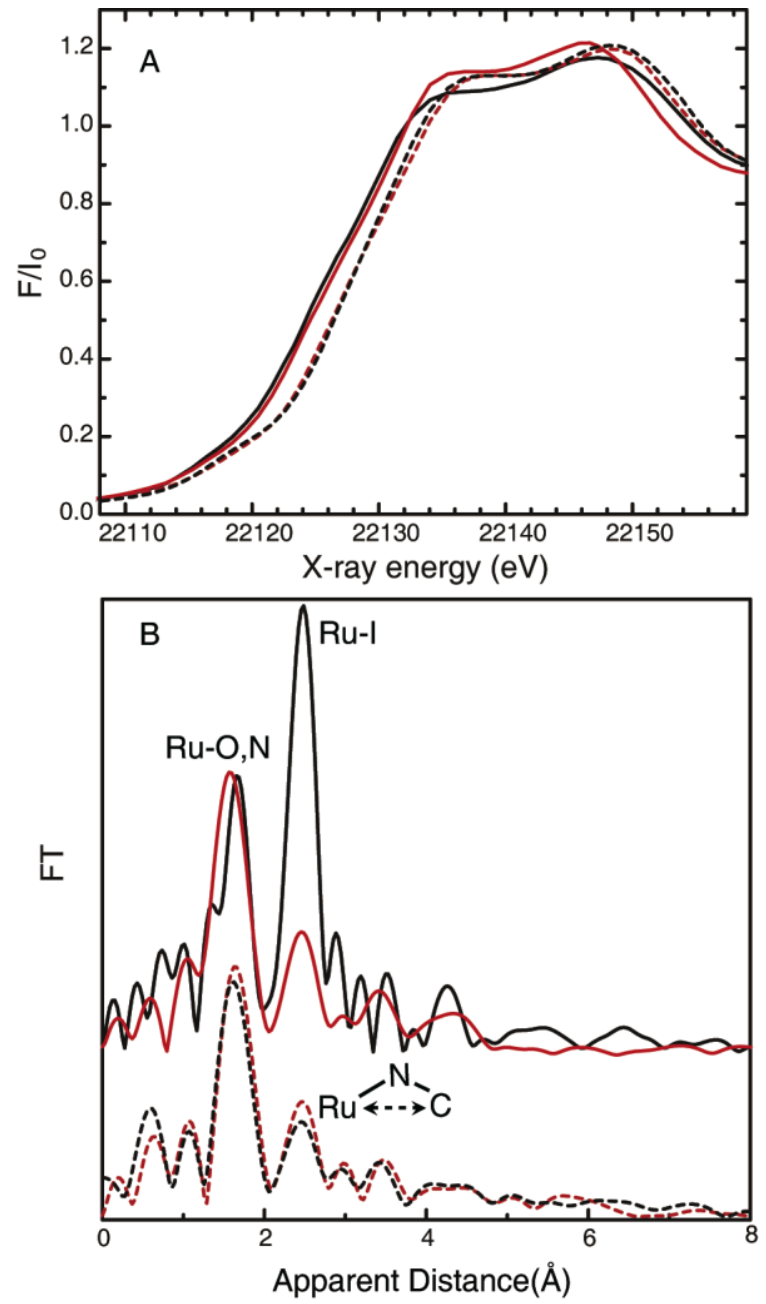

Figure 3. Normalized Ru K-edge XANES (A) and Fourier transforms of $k^{3}$-weighted Ru EXAFS (B) of the starting $\left[\mathrm{Ru}^{\mathrm{II}}(\mathrm{bpy})(\mathrm{tpy}) \mathrm{I}\right]^{+}$(black) and $\left[\mathrm{Ru}{ }^{\mathrm{II}}(\mathrm{bpy})(\mathrm{tpy}) \mathrm{H}_{2} \mathrm{O}\right]^{2+}$ (red) complexes; $\left[\mathrm{Ru}^{\mathrm{II}}(\mathrm{bpy})(\mathrm{tpy}) \mathrm{I}\right]^{+}$complex oxidized with 20 equiv (black dashed line) of $\mathrm{Ce}^{\mathrm{IV}}$ and $\left[\mathrm{Ru}^{\mathrm{II}}(\mathrm{bpy})(\mathrm{tpy}) \mathrm{H}_{2} \mathrm{O}\right]^{2+}$ oxidized with 20 equiv of $\mathrm{Ce}^{\mathrm{IV}}$ (red dashed line). There is $1 \mathrm{mM}$ catalyst concentration in $0.1 \mathrm{M} \mathrm{HNO}_{3}$.

$\mathrm{Ru}$ K-edge EXAFS was used to verify changes in the Ru-I interaction during oxidation (Figure 2B). Ru-I absorber-backscatter pair gives an intense peak at an apparent distance of $2.4 \AA$. The 
intensity of this peak decreases with addition of 1 and 2 equiv of $\mathrm{Ce}^{\mathrm{IV}}$ and fully disappears after adding 20 equiv. Thus, addition of even 1 and 2 equiv of $\mathrm{Ce}^{\mathrm{IV}}$ already decreases the number of complexes with a Ru-I bond. Under catalytic conditions, the Ru-I interaction disappears within $30 \mathrm{sec}$ of sample mixing. EXAFS results firmly rule out the presence of a Ru-I bond under catalytic conditions and thus the formation of 7-coordinated intermediate $\left(\left[\mathrm{Ru}^{\mathrm{x}}(\mathrm{bpy})(\mathrm{tpy})\left(\mathrm{H}_{2} \mathrm{O}\right) \mathrm{I}\right]^{\mathrm{x}-1}\right.$ as a catalytically relevant species. The behavior of $\left[\mathrm{Ru}^{\mathrm{II}}(\mathrm{bpy})(\mathrm{tpy}) \mathrm{I}\right]$ is critically different from the analogous $\left[\mathrm{Ru}{ }^{\mathrm{II}}(\mathrm{bpy})(\mathrm{tpy}) \mathrm{Cl}\right]$ complex. While both complexes engage in halogen exchange with solvent when the $\mathrm{Ru}$ center is in the oxidation state $2+$ with $50 \%$ conversion at $3 \mathrm{~h}(\mathrm{Ru}-\mathrm{Cl})$ and $4.3 \mathrm{~h}(\mathrm{Ru}-\mathrm{I})$ as determined by NMR studies [3], stabilization of the $\mathrm{Ru}-\mathrm{Cl}$ bond was observed upon oxidation of the catalyst with $\mathrm{Ce}^{\mathrm{IV}}[8] . \mathrm{Cl}$ exchange in the $\mathrm{Ru}^{\mathrm{II}}-\mathrm{Cl}$ complexes is well documented in the literature [28-30], while fewer studies are available for $\mathrm{Ru}^{\mathrm{III}}$ complexes. One would expect that $\mathrm{Ru}^{\mathrm{III}}$ with increased positive charge will bind negatively charged halogen ligand much stronger. To verify this we directly monitored the $\mathrm{Ru}-\mathrm{Cl}$ bond under various reaction conditions by $\mathrm{Cl}$ K-edge XANES (Figure 4). We have used the effect described earlier for complexes with $\mathrm{Mn}-\mathrm{Cl}$ [31] and $\mathrm{V}-\mathrm{Br}$ [32] bonds, namely the appearance of the pre-edge in the $\mathrm{Cl}$ absorption K-edge upon binding to the transition metal. Figure 4(A) shows $\mathrm{Cl}$ K-edge XANES for [Ru $\left.{ }^{\mathrm{II}}(\mathrm{bpy})(\mathrm{tpy}) \mathrm{Cl}\right] \mathrm{Cl}$ incubated in water for $2 \mathrm{~min}, 30$ min and 4 hours and frozen for XANES analysis. The spectra show two pre-edge peaks at 2821.8 and $2822.8 \mathrm{eV}$. Their intensities decreases significantly after incubation for 4 hours which is in good agreement with earlier NMR studies [3]. Figure 4B shows $\mathrm{Cl}$ K-edge spectra of $\left[\mathrm{Ru}^{\mathrm{III}}(\mathrm{bpy})(\mathrm{tpy}) \mathrm{Cl}\right]^{2+}$ generated by oxidation with 1 

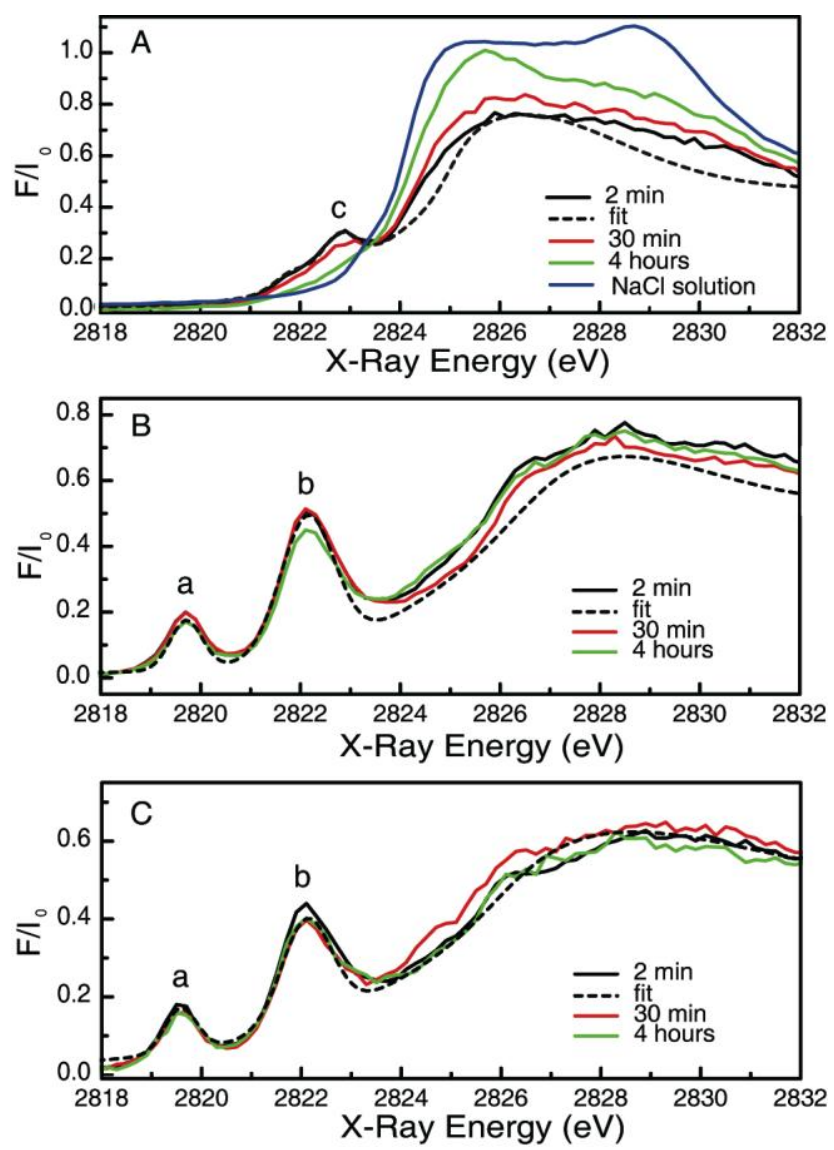

Figure 4. (A) $\mathrm{Cl}$ K-edge of $\left[\mathrm{Ru}^{\mathrm{II}}(\mathrm{bpy})(\mathrm{tpy}) \mathrm{Cl}\right]^{+}$dissolved in water and frozen after $2 \mathrm{~min}, 30 \mathrm{~min}$ and 4 hours. Water solution of $\mathrm{NaCl}$ is displayed for comparison to show spectrum of free $\mathrm{Cl}^{-}$ ion. (B) $\mathrm{Cl} \mathrm{K}$-edge of $\left[\mathrm{Ru}^{\mathrm{III}}(\mathrm{bpy})(\mathrm{tpy}) \mathrm{Cl}\right]^{2+}$ prepared by oxidation of $\left[\mathrm{Ru}^{\mathrm{II}}(\mathrm{bpy})(\mathrm{tpy}) \mathrm{Cl}\right]^{+}$with 1 eq of $\mathrm{Ce}^{\mathrm{IV}}$ and frozen 2 min, 30 min and 4 hours after preparation. (C) $\mathrm{Cl}$ K-edge of $\left[\mathrm{Ru}^{\mathrm{II}}(\mathrm{bpy})(\mathrm{tpy}) \mathrm{Cl}\right]^{+}$oxidized with $20 \mathrm{eq}$ of $\mathrm{Ce}^{\mathrm{IV}}$ and frozen $2 \mathrm{~min}, 30 \mathrm{~min}$ and 4 hours after preparation. $1 \mathrm{mM}$ catalyst concentration in $0.1 \mathrm{M} \mathrm{HNO}_{3}$

equiv of $\mathrm{Ce}^{\mathrm{IV}}$. Interestingly, $\left[\mathrm{Ru}^{\mathrm{III}}(\mathrm{bpy})(\mathrm{tpy}) \mathrm{Cl}\right]^{2+}$ shows more intense and further separated preedge peaks with maximums at 2819.7 and $2822.1 \mathrm{eV}$. This is likely due to an increase in the Ru$\mathrm{Cl}$ orbital mixing due to shortening of the $\mathrm{Ru}-\mathrm{Cl}$ bond in the $\left[\mathrm{Ru}{ }^{\mathrm{III}}(\mathrm{bpy})(\mathrm{tpy}) \mathrm{Cl}\right]^{2+}$ complex. When freshly dissolved (less than 2 minutes) $\left[\mathrm{Ru}^{\mathrm{II}}(\mathrm{bpy})(\mathrm{tpy}) \mathrm{Cl}\right] \mathrm{Cl}$ is oxidized with 1 equiv of 
$\mathrm{Ce}^{\mathrm{IV}}$ to generate $\left[\mathrm{Ru}^{\mathrm{III}}(\mathrm{bpy})(\mathrm{tpy}) \mathrm{Cl}\right]^{2+}$ and the latter is left in solution for an extended period of time (up to 4 hours) no decrease in pre-edge intensity with time was noted (Figure 4B). To check stability of the $\mathrm{Ru}-\mathrm{Cl}$ bond under catalytic conditions, we measured catalytic mixtures prepared with 20 equiv of $\mathrm{Ce}^{\mathrm{IV}}$, Figure 4C. We found that the amount of oxidant (up to 20 equiv) does not affect exchangeability of $\mathrm{Ru}^{\mathrm{III}}-\mathrm{Cl}$ and does not cause $\mathrm{Ru}-\mathrm{Cl}$ bond dissociation.

The behavior of $\left[\mathrm{Ru}^{\mathrm{III}}(\mathrm{bpy})(\mathrm{tpy}) \mathrm{I}\right]^{2+}$ is critically different and cannot be predicted based on the behavior of the $\left[\mathrm{Ru}^{\text {III }}(\mathrm{bpy})(\mathrm{tpy}) \mathrm{Cl}\right]^{2+}$ complex or available literature. The instability of $\left[\mathrm{Ru}^{\mathrm{III}}(\mathrm{bpy})(\mathrm{tpy}) \mathrm{I}\right]^{2+}$ can be rationalized by the following proposed reaction sequence which implies homolytic dissociation of Ru-I occurring much faster than ligand exchange:

$$
\begin{aligned}
& {\left[\mathrm{Ru}^{\text {II }}(\text { bpy })(\text { tpy })\right]^{+}-1 \mathrm{e}^{-} \rightarrow\left[\mathrm{Ru}^{\mathrm{III}}(\text { bpy })(\text { tpy })\right]^{2+}} \\
& {\left[\mathrm{Ru}^{\mathrm{III}}(\text { bpy })(\text { tpy })\right]^{2+} \rightarrow\left[\mathrm{Ru}^{\mathrm{II}}(\text { bpy })(\text { tpy })\right]^{2+}+\mathrm{I}^{\cdot}} \\
& {\left[\mathrm{Ru}^{\mathrm{II}}(\text { bpy })(\text { tpy })\right]^{2+}+\mathrm{H}_{2} \mathrm{O} \rightarrow\left[\mathrm{Ru}^{\mathrm{II}}(\text { bpy })(\text { tpy }) \mathrm{H}_{2} \mathrm{O}\right]^{2+}}
\end{aligned}
$$

From this scheme it follows that the $[R u(b p y)(t p y) I] I$ complex converts into $\left[\mathrm{Ru}^{\mathrm{II}}(\mathrm{bpy})(\mathrm{tpy}) \mathrm{H}_{2} \mathrm{O}\right]^{2+}$ upon oxidation and final product of $\mathrm{I}^{-}$oxidation is likely $\mathrm{IO}_{3}{ }^{-}$according to its Pourbaix diagram [26]. To verify this, Figure 3 compares XANES and EXAFS spectra of the starting $\left[\mathrm{Ru}(\mathrm{bpy})(\mathrm{tpy}) \mathrm{H}_{2} \mathrm{O}\right]^{2+}$ and $[\mathrm{Ru}(\mathrm{bpy})(\mathrm{tpy}) \mathrm{I}] \mathrm{I}$ catalysts and catalytic species in these two systems achieved upon oxidation with 20 equiv of $\mathrm{Ce}^{\mathrm{IV}}$. While XANES and EXAFS of the starting materials are very different, spectra of their reaction mixtures are virtually identical. The inflection points of 20 equiv $\mathrm{Ce}^{\mathrm{IV}}\left[\mathrm{Ru}(\mathrm{bpy})(\mathrm{tpy}) \mathrm{H}_{2} \mathrm{O}\right]^{2+}$ and $[\mathrm{Ru}($ bpy)(tpy)I]I spectra are the same indicating the oxidation state of the iodine complex is $\mathrm{Ru}^{\mathrm{IV}}$. The $\mathrm{Ru}^{\mathrm{IV}}$ oxidation state was earlier verified for $\left[\mathrm{Ru}\left(\text { bpy) }(\text { tpy }) \mathrm{H}_{2} \mathrm{O}\right]^{2+}\right.$ using XANES with reference 
Table 1. Parameters of EXAFS fits

\begin{tabular}{|c|c|c|c|c|c|}
\hline Fit & Shell, $\mathrm{N}^{a}$ & $\mathrm{R}, \AA$ & $\sigma^{2}\left(10^{-3}\right)$ & $\begin{array}{l}\text { R- } \\
\text { factor }\end{array}$ & $\begin{array}{l}\text { Reduced } \chi- \\
\text { square }\end{array}$ \\
\hline \multicolumn{6}{|c|}{$\left[\mathrm{Ru}{ }^{\mathrm{II}}(\mathrm{bpy})(\mathrm{tpy}) \mathrm{I}\right]^{1+}$} \\
\hline 1 & $\mathrm{Ru}-\mathrm{N}, 6$ & 2.04 & 5.7 & 0.874 & 44403 \\
\hline \multirow[t]{2}{*}{2} & $\mathrm{Ru}-\mathrm{N}, 5$ & 2.07 & 4.6 & 0.032 & 2060 \\
\hline & Ru-I, 1 & 2.73 & 1.2 & & \\
\hline \multirow[t]{3}{*}{3} & $\mathrm{Ru}-\mathrm{N}, 5$ & 2.08 & 4.7 & 0.004 & 327 \\
\hline & Ru-I, 1 & 2.74 & 1.2 & & \\
\hline & $\mathrm{Ru}-\mathrm{C}, 10$ & 3.13 & 14.4 & & \\
\hline \multicolumn{6}{|c|}{$\left[\mathrm{Ru}^{\mathrm{II}}(\text { bpy)(tpy)I}]^{\mathrm{I+}}+1\right.$ equiv $\mathrm{Ce}^{\mathrm{IV}}$} \\
\hline \multirow[t]{3}{*}{4} & Ru-N, 5 & 2.09 & 3.6 & 0.011 & 284 \\
\hline & Ru-I, 1 & 2.75 & 2.0 & & \\
\hline & $\mathrm{Ru}-\mathrm{C}, 10$ & 3.15 & 15.8 & & \\
\hline \multicolumn{6}{|c|}{$\left[\mathrm{Ru}^{\mathrm{II}}(\mathrm{bpy})(\mathrm{tpy}) \mathrm{I}\right]^{\mathrm{I}+}+2$ equiv $\mathrm{Ce}^{\mathrm{IV}}$} \\
\hline \multirow[t]{3}{*}{5} & Ru-N, 5 & 2.05 & 3.2 & 0.040 & 365 \\
\hline & Ru-I, 1 & 2.74 & 3.5 & & \\
\hline & $\mathrm{Ru}-\mathrm{C}, 10$ & 2.92 & 3.5 & & \\
\hline
\end{tabular}




\begin{tabular}{|c|c|c|c|c|c|}
\hline 6 & $\begin{array}{l}\text { Ru-N, } 5 \\
\text { Ru-I, } 0.5 \\
\text { Ru-C, } 10\end{array}$ & $\begin{array}{l}2.05 \\
2.73 \\
2.94\end{array}$ & $\begin{array}{l}3.6 \\
1.1 \\
5.0\end{array}$ & 0.040 & 365 \\
\hline \multicolumn{6}{|c|}{$\left[\mathrm{Ru}^{\mathrm{II}}(\mathrm{bpy})(\mathrm{tpy}) \mathrm{I}\right]^{\mathrm{I}+}+20$ equiv $\mathrm{Ce}^{\mathrm{IV}}$, peak I } \\
\hline 7 & $\mathrm{Ru}-\mathrm{N}, 6$ & 2.07 & 5.7 & 0.074 & 2286 \\
\hline 8 & $\begin{array}{l}\mathrm{Ru}-\mathrm{O}, 1 \\
\mathrm{Ru}-\mathrm{N}, 5\end{array}$ & $\begin{array}{l}1.78^{b} \\
2.09\end{array}$ & $\begin{array}{l}4.4 \\
5.2\end{array}$ & 0.001 & 543 \\
\hline \multicolumn{6}{|c|}{$\left[\mathrm{Ru}^{\mathrm{II}}(\text { bpy) (tpy)I }]^{\mathrm{I+}}+20\right.$ equiv $\mathrm{Ce}^{\mathrm{IV}}$} \\
\hline 9 & $\mathrm{Ru}-\mathrm{N}, 6$ & 2.07 & 6.0 & 0.419 & 1636 \\
\hline 10 & $\begin{array}{l}\text { Ru-N, } 6 \\
\text { Ru-C, } 10\end{array}$ & $\begin{array}{l}2.04 \\
2.91\end{array}$ & $\begin{array}{l}5.2 \\
7.6\end{array}$ & 0.123 & 623 \\
\hline 11 & $\begin{array}{l}\text { Ru-O, } 1 \\
\text { Ru-N, } 5 \\
\text { Ru-I, } 0.1 \\
\text { Ru-C, } 10\end{array}$ & $\begin{array}{l}1.77^{b} \\
2.09 \\
2.69 \\
3.6\end{array}$ & $\begin{array}{l}3.1 \\
5.6 \\
0.03 \\
\\
13.9\end{array}$ & 0.047 & 568 \\
\hline 12 & $\begin{array}{l}\text { Ru-N, } 6 \\
\text { Ru-I, } 0.1\end{array}$ & $\begin{array}{l}2.06 \\
2.67\end{array}$ & $\begin{array}{l}5.6 \\
0.7\end{array}$ & 0.101 & 719 \\
\hline
\end{tabular}




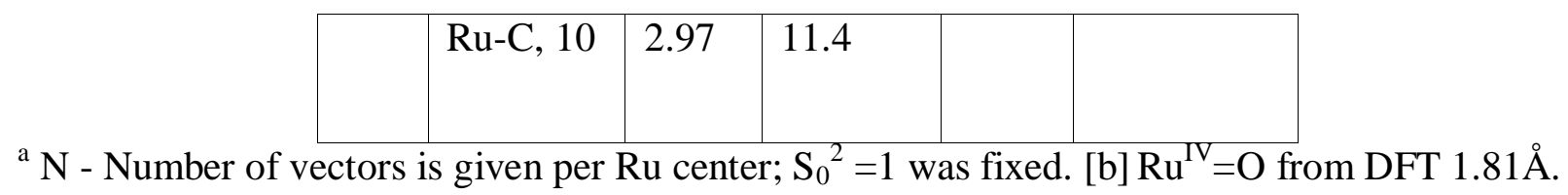

compounds and EPR [8]. Both $\left[\mathrm{Ru}(\mathrm{bpy})(\mathrm{tpy}) \mathrm{H}_{2} \mathrm{O}\right]^{2+}$ and $[\mathrm{Ru}(\mathrm{bpy})($ tpy)I]I catalyst achieve close to $95 \%$ conversion to the $\mathrm{Ru}^{\mathrm{IV}}$ oxidation state (Figure $3 \mathrm{~A}$ ). Table 1 compares EXAFS fits for the complexes under catalytic $[\mathrm{Ru}(\mathrm{bpy})(\mathrm{tpy}) \mathrm{I}] \mathrm{I}$ complexes [3]. This is in good agreement with spectroscopic results which show virtually indistinguishable structures of Ru species under catalytic conditions. However, $[\mathrm{Ru}(\mathrm{bpy})(\mathrm{tpy}) \mathrm{I}] \mathrm{I}$ eventually evolved about twice as much oxygen as shown by their turnover numbers (TON) [3]. The previous $\mathrm{O}_{2}$ evolution results were reported for $\mathrm{PF}_{6}^{-}$salts and catalysts were introduced into reaction mixture in acetonitrile [3]. We remeasured $\mathrm{O}_{2}$ evolution using the same compounds and same conditions as in spectroscopic experiments with a Clark electrode immersed in the reaction mixture (Figure S4). Figure S4 shows that $[\mathrm{Ru}(\mathrm{bpy})(\mathrm{tpy}) \mathrm{I}] \mathrm{I}$ is less active than $\left[\mathrm{Ru}(\mathrm{bpy})(\mathrm{tpy}) \mathrm{H}_{2} \mathrm{O}\right]^{2+}$ under the condition of relatively low (20 equiv) $\mathrm{Ce}^{\mathrm{IV}}$ concentration. This is not surprising and is in agreement with the trend observed by EPR. Some $\mathrm{Ce}^{\mathrm{IV}}$ equivalents are used oxidizing an iodide ligand which effectively lowers the $\mathrm{Ce}^{\mathrm{IV}}$ concentration and results in less efficient catalysis. This effect is less apparent under large (5000 equiv) excess of $\mathrm{Ce}^{\mathrm{IV}}$ used for determination of TON. Under such condition, the initial rates of $\mathrm{O}_{2}$ evolution are the same for both complexes [3] showing a minimal effect of $\mathrm{I}^{-}$ligand on the overall mechanism. The presence of $5 \% \mathrm{CF}_{3} \mathrm{CH}_{2} \mathrm{OH}$ in the reaction mixture results in the delayed (by about $50 \mathrm{~s}$ ) $\mathrm{O}_{2}$ evolution for $\mathrm{Ru}\left(\text { bpy)(tpy) } \mathrm{H}_{2} \mathrm{O}\right]^{2+}$ complex (Figure S4). [Ru(bpy)(tpy)I]I is not soluble in water and thus was studied only in 5\% $\mathrm{CF}_{3} \mathrm{CH}_{2} \mathrm{OH}$. 


\section{Conclusions}

$[\mathrm{Ru}(\mathrm{bpy})(\mathrm{tpy}) \mathrm{I}] \mathrm{I}$ water oxidizing catalyst displays ligand lability, quickly loses the rutheniumiodine bond upon oxidation and generates $\left[\mathrm{Ru}^{\mathrm{IV}}(\mathrm{bpy})(\mathrm{tpy})=\mathrm{O}\right]^{2+}$ reactive species. This behavior contrasts the properties of $[\mathrm{Ru}(\mathrm{bpy})(\mathrm{tpy}) \mathrm{Cl}] \mathrm{Cl}$ which retains $\mathrm{Ru}-\mathrm{Cl}$ bond and does not serve as a water oxidation catalyst. Thus, the formation of the $\left[\mathrm{Ru}^{\mathrm{IV}}(\mathrm{bpy})(\mathrm{tpy})=\mathrm{O}\right]^{2+}$ is a prerequisite for water oxidation catalysis. A detailed mechanism of its reaction with water (directly or via other intermediates) is currently unknown. X-ray spectroscopy is broadly applicable to a wide range of transition metal catalysts where catalyst precursor or catalytically relevant species having a transition metal-halogen bond. XANES at the $\mathrm{Cl} \mathrm{K}$-edge allows quick measurement and reports on both the presence of a metal- $\mathrm{Cl}$ bond and electronic structure (oxidation state) of the metal center under catalytic conditions.

\section{Notes and references}

Supporting information: EPR spectra, $\mathrm{O}_{2}$ evolution results.

The authors declare no competing financial interests.

\section{ACKNOWLEDGMENT}

This material is based upon work supported by the U.S. Department of Energy, Office of Sciences, Office of Basic Energy Sciences under grant numbers DE-FG02-10ER16184 (Y.P.). Work at UH was carried out under contract DE-FG02-07ER15888 with the U.S. Department of Energy and supported by its Division of Chemical Sciences, Geosciences, \& Biosciences, Office of Basic Energy Sciences. Use of the Advanced Photon Source, an Office of Science User Facility operated by the U.S. Department of Energy (DOE) Office of Science by Argonne National Laboratory, was supported by the U.S. DOE under Contract DE-AC02-06CH11357. PNC/XSD (Sector 20) facilities at the Advanced Photon Source, and research at these facilities, 
are supported by the US Department of Energy - Basic Energy Science, the Canadian Light Source and its funding partners, the University of Washington, and the Advanced Photon Source.

We thank Dr. Steve Heald and Dr. Dale Brewe for help with experiments at Beamline BM-20, APS and Prof. Randolph Thummel for helpful discussions. Access to EPR was provided by the Amy Instrumentation Facility, Department of Chemistry under the supervision of Dr. Michael Everly.

\section{References}

[1] T. Naota, H. Takaya, S.I. Murahashi, Ruthenium-catalyzed reactions for organic synthesis, Chem. Rev., 98 (1998) 2599-2660.

[2] P.G. Jessop, Y. Hsiao, T. Ikariya, R. Noyori, Homogeneous catalysis in supercritical fluids: Hydrogenation of supercritical carbon dioxide to formic acid, alkyl formates, and formamides, J. Am. Chem. Soc., 118 (1996) 344-355.

[3] N. Kaveevivitchai, R.F. Zong, H.W. Tseng, R. Chitta, R.P. Thummel, Further Observations on Water Oxidation Catalyzed by Mononuclear Ru(II) Complexes, Inorg. Chem., 51 (2012) 29302939.

[4] J.L. Boyer, D.E. Polyansky, D.J. Szalda, R.F. Zong, R.P. Thummel, E. Fujita, Effects of a Proximal Base on Water Oxidation and Proton Reduction Catalyzed by Geometric Isomers of [Ru(tpy)(pynap)(OH2)](2+), Angew. Chem.-Int. Edit., 50 (2011) 12600-12604.

[5] H.W. Tseng, R. Zong, J.T. Muckerman, R. Thummel, Mononuclear Ruthenium(II) Complexes That Catalyze Water Oxidation, Inorg. Chem., 47 (2008) 11763-11773.

[6] Z.F. Chen, J.J. Concepcion, X.Q. Hu, W.T. Yang, P.G. Hoertz, T.J. Meyer, Concerted O atomproton transfer in the O-O bond forming step in water oxidation, Proc. Natl. Acad. Sci. U. S. A., 107 (2010) 7225-7229. 
[7] J.J. Concepcion, M.K. Tsai, J.T. Muckerman, T.J. Meyer, Mechanism of Water Oxidation by Single-Site Ruthenium Complex Catalysts, J. Am. Chem. Soc., 132 (2010) 1545-1557.

[8] Y. Pushkar, D. Moonshiram, V. Purohit, L. Yan, I. Alperovich, Spectroscopic Analysis of Catalytic Water Oxidation by $[\mathrm{RuII}(\mathrm{bpy})(\mathrm{tpy}) \mathrm{H} 2 \mathrm{O}] 2+$ Suggests That $\mathrm{RuV}=\mathrm{O}$ Is Not a RateLimiting Intermediate, J. Am. Chem. Soc., 136 (2014) 11938-11945.

[9] L.L. Duan, F. Bozoglian, S. Mandal, B. Stewart, T. Privalov, A. Llobet, L.C. Sun, A molecular ruthenium catalyst with water-oxidation activity comparable to that of photosystem II, Nat. Chem., 4 (2012) 418-423.

[10] I. Lopez, M.Z. Ertem, S. Maji, J. Benet-Buchholz, A. Keidel, U. Kuhlmann, P. Hildebrandt, C.J. Cramer, V.S. Batista, A. Llobet, A Self-Improved Water-Oxidation Catalyst: Is One Site Really Enough?, Angew. Chem.-Int. Edit., 53 (2014) 205-209.

[11] S. Goberna-Ferrón, B. Peña, J. Soriano-López, J.J. Carbó, H. Zhao, J.M. Poblet, K.R. Dunbar, J.R. Galán-Mascarós, A fast metal-metal bonded water oxidation catalyst, J. Catal., 315 (2014) 25-32.

[12] D.K. Zhong, S. Zhao, D.E. Polyansky, E. Fujita, Diminished photoisomerization of active ruthenium water oxidation catalyst by anchoring to metal oxide electrodes, J. Catal., 307 (2013) $140-147$.

[13] L. Wang, L. Duan, L. Tong, L. Sun, Visible light-driven water oxidation catalyzed by mononuclear ruthenium complexes, J. Catal., 306 (2013) 129-132.

[14] Q. Zeng, F.W. Lewis, L.M. Harwood, F. Hartl, Role of ligands in catalytic water oxidation by mononuclear ruthenium complexes, Coord. Chem. Rev., (2015). 
[15] T.J. Meyer, M.H.V. Huynh, H.H. Thorp, The possible role of proton-coupled electron transfer (PCET) in water oxidation by photosystem II, Angew. Chem. Int. Ed., 46 (2007) 52845304.

[16] D. Moonshiram, J.W. Jurss, J.J. Concepcion, T. Zakharova, I. Alperovich, T.J. Meyer, Y. Pushkar, Structure and electronic configurations of the intermediates of water oxidation in blue ruthenium dimer catalysis, J. Am. Chem. Soc., 134 (2012) 4625-4636.

[17] S. Masaoka, K. Sakai, Clear Evidence Showing the Robustness of a Highly Active Oxygenevolving Mononuclear Ruthenium Complex with an Aqua Ligand, Chem. Lett., 38 (2009) 182183.

[18] D.J. Wasylenko, C. Ganesamoorthy, M.A. Henderson, B.D. Koivisto, H.D. Osthoff, C.P. Berlinguette, Electronic Modification of the $[\mathrm{Ru}-\mathrm{II}(\mathrm{tpy})(\mathrm{bpy})(\mathrm{OH} 2)](2+)$ Scaffold: Effects on Catalytic Water Oxidation, J. Am. Chem. Soc., 132 (2010) 16094-16106.

[19] N. Kaveevivitchai, L. Kohler, R. Zong, M. El Ojaimi, N. Mehta, R.P. Thummel, A Ru(II) Bis-terpyridine-like Complex that Catalyzes Water Oxidation: The Influence of Steric Strain, Inorg. Chem., 52 (2013) 10615-10622.

[20] L.L. Duan, A. Fischer, Y.H. Xu, L.C. Sun, Isolated Seven-Coordinate Ru(IV) Dimer Complex with [HOHOH](-) Bridging Ligand as an Intermediate for Catalytic Water Oxidation, J. Am. Chem. Soc., 131 (2009) 10397-10399.

[21] L. Wang, L. Duan, Y. Wang, M.S.G. Ahlquist, L.C. Sun, Highly efficient and robust molecular water oxidation catalysts based on ruthenium complexes, Chem. Commun., 50 (2014) 12947-12950.

[22] A.C. Dengel, W.P. Griffith, C.A. Omahoney, D.J. Williams, A Stable Ruthenium(V) Oxo Complex - X-Ray Crystal-Structure and Oxidizing Properties of Tetra-N-Propylammonium Bis- 
2-Hydroxy-2-Ethylbutyrato(Oxo)-Ruthenate(V), J. Chem. Soc.-Chem. Commun., (1989) 17201721.

[23] B. Ravel, M. Newville, ATHENA, ARTEMIS, HEPHAESTUS: data analysis for X-ray absorption spectroscopy using IFEFFIT, J. Synchrot. Radiat., 12 (2005) 537-541.

[24] J.J. Rehr, R.C. Albers, Theoretical approaches to x-ray absorption fine structure, Rev. Mod. Phys., 72 (2000) 621-654.

[25] D.C. Koningsberger, R. Prins, X Ray Absorption: Principles, Applications, Techniques of EXAFS, SEXAFS and XANES, John Wiley \& Sons, 1988.

[26] A.R. Parent, T.P. Brewster, W. De Wolf, R.H. Crabtree, G.W. Brudvig, Sodium Periodate as a Primary Oxidant for Water-Oxidation Catalysts, Inorg. Chem., 51 (2012) 6147-6152.

[27] D. Moonshiram, I. Alperovich, J.J. Concepcion, T.J. Meyer, Y. Pushkar, Experimental demonstration of radicaloid character in a $\mathrm{Ru}-\mathrm{V}=\mathrm{O}$ intermediate in catalytic water oxidation, Proc. Natl. Acad. Sci. U. S. A., 110 (2013) 3765-3770.

[28] E.C. Johnson, B.P. Sullivan, D.J. Salmon, S.A. Adeyemi, T.J. Meyer, SYNTHESIS AND PROPERTIES OF CHLORO-BRIDGED DIMER (BPY)2RUCL 22+ AND ITS TRANSIENT 3+ MIXED-VALENCE ION, Inorg. Chem., 17 (1978) 2211-2215.

[29] F.P. Dwyer, H.A. Goodwin, E.C. Gyarfas, MONO- AND BIS-(2,2-BIPYRIDINE) AND (1,10-PHENANTHROLINE) CHELATES OF RUTHENIUM AND OSMIUM .2. BISCHELATES OF BIVALENT AND TERVALENT RUTHENIUM, Aust. J. Chem., 16 (1963) 544-548.

[30] M. Rodriguez, I. Romero, A. Llobet, A. Deronzier, M. Biner, T. Parella, H. Stoeckli-Evans, Synthesis, structure, and redox and catalytic properties of a new family of ruthenium complexes containing the tridentate bpea ligand, Inorg. Chem., 40 (2001) 4150-4156. 
[31] A. Rompel, J.C. Andrews, R.M. Cinco, M.W. Wemple, G. Christou, N.A. Law, V.L. Pecoraro, K. Sauer, V.K. Yachandra, M.P. Klein, Chlorine K-Edge X-ray Absorption Spectroscopy as a Probe of Chlorine-Manganese Bonding: Model Systems with Relevance to the Oxygen Evolving Complex in Photosystem II, J. Am. Chem. Soc., 119 (1997) 4465-4470.

[32] H. Dau, J. Dittmer, M. Epple, J. Hanss, E. Kiss, D. Rehder, C. Schulzke, H. Vilter, Bromine K-edge EXAFS studies of bromide binding to bromoperoxidase from Ascophyllum nodosum, FEBS Lett., 457 (1999) 237-240. 
Graphical Abstract

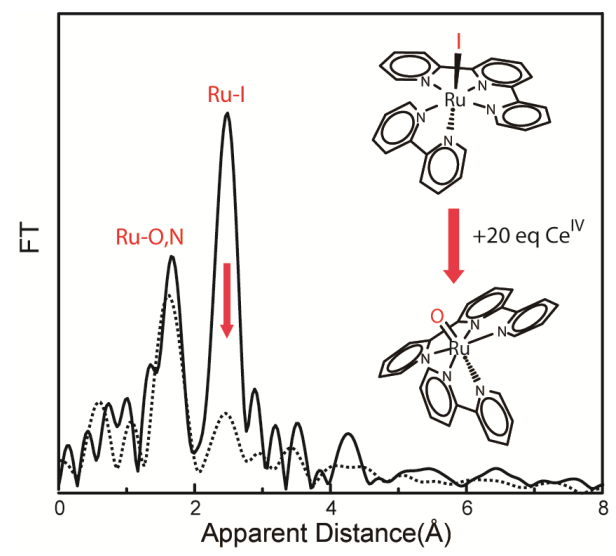


$\left[\mathrm{Ru} \mathrm{u}^{\mathrm{II}}(\mathrm{bpy})(\mathrm{tpy}) \mathrm{I}\right]^{+}$was reported to have enhanced catalytic activity in water oxidation.

EPR and X-ray absorption spectroscopy were used to study catalytic mechanism.

We determined that Ru-iodide bond is not sustained under catalytic conditions.

$\left[\mathrm{Ru}^{\mathrm{II}}(\mathrm{bpy})(\mathrm{tpy}) \mathrm{I}\right]^{+}$serves as a precursor to a $\left[\mathrm{Ru}^{\mathrm{IV}}(\mathrm{bpy})(\mathrm{tpy})=\mathrm{O}\right]^{2+}$ catalytic intermediate.

$\left[\mathrm{Ru} \mathrm{u}^{\mathrm{II}}(\mathrm{bpy})(\mathrm{tpy}) \mathrm{Cl}\right]^{+}$sustains $\mathrm{Ru}-\mathrm{Cl}$ bond and is not a catalysts for water oxidation. 